\title{
Anti-inflammatory effect of lycopene on endotoxin-induced uveitis in rats
}

\author{
Efeito anti-inflamatório do licopeno na uveíte induzida por endotoxina em ratos
}

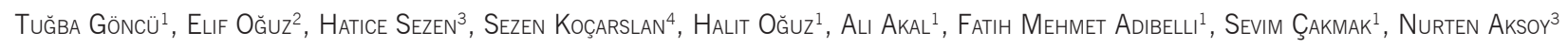

\begin{abstract}
Purpose: We evaluated the efficacy of lycopene, a dietary carotenoid and potent antioxidant, against ocular inflammation and oxidative stress in an experimental uveitis model.

Methods: Endotoxin-induced uveitis (EIU) was induced in Sprague-Dawley rats by a single subcutaneous injection of $200 \mathrm{\mu g}$ lipopolysaccharide (LPS). Induction of EIU was preceded by daily intraperitoneal injection of $10 \mathrm{mg} / \mathrm{kg}$ lycopene for three consecutive days (Lycopene + LPS group) or equivolume vehicle (Vehicle + LPS group). A positive control group received $1 \mathrm{mg} / \mathrm{kg}$ dexamethasone pretreatment (DEX + LPS), and a negative control group received daily vehicle injection but no LPS (Vehicle Control). Twenty-four hours after LPS or final vehicle administration, eyes were enucleated, and aqueous humor was collected for measurement of the number of infiltrating cells, total protein concentration, and levels of nitric oxide (NO), tumor necrosis factor-a (TNF-a), interleukin-6 (IL-6), and oxidative stress markers. Inflammatory response severity was compared among groups clinically and histopathologically.

Results: Infiltrating cell number, total protein concentration, and NO, TNF-a, and IL-6 levels were significantly elevated in the aqueous humor of Vehicle + LPS group rats compared to Vehicle Controls. Compared to the Vehicle + LPS group, lycopene pretreatment significantly reduced aqueous humor concentrations of oxidative stress markers, $\mathrm{NO}(0.29 \pm 0.1 \mu \mathrm{M}$ vs. $0.19 \pm 0.1 \mu \mathrm{M}, \mathrm{p}=0.003)$. TNF- $\mathrm{a}$ $(71.0 \pm 22.3 \mathrm{ng} / \mathrm{ml}$ vs. $50.1 \pm 2.1 \mathrm{ng} / \mathrm{ml}, \mathrm{p}=0.043)$, and $\mathrm{IL}-6(121.6 \pm 3.0 \mathrm{pg} / \mathrm{ml}$ vs. $111.1 \pm 5.6 \mathrm{pg} / \mathrm{ml}, \mathrm{p}=0.008)$. Inflammatory score was also reduced ( $2.0 \pm 0.0 \mathrm{vs}$. $0.4 \pm 0.5, p=0.001)$. Lycopene reduced the infiltrating cell count and protein concentration, but differences did not reach significance. Most lycopene effects were equivalent to dexamethasone.
\end{abstract}

Conclusions: Lycopene may aid in the clinical management of uveitis by suppressing inflammation and oxidative stress.

Keywords: Uveitis/chemically induced; Endotoxins; Oxidative stress; Antioxidants; Inflammation; Cytokines; Animals; Disease models, animal; Rats

\section{RESUMO}

Objetivo: Avaliamos o efeito do licopeno, um carotenóide dietético e um potente anti-oxidante, sobre a inflamação ocular e estresse oxidativo em modelo de uveíte experimental.

Métodos: Uveíte foi induzida por endotoxina (EIU) em ratos Sprague-Dawley por uma única injeção subcutânea de 200 ug de lipopolissacárido (LPS). A indução de EIU foi precedida por injeção intraperitoneal de licopeno em uma dose de $10 \mathrm{mg} / \mathrm{kg}$ (grupo LPS + Licopeno) ou veículo de mesmo volume (grupo LPS + Veículo), durante 3 dias consecutivos. O grupo controle positivo recebeu uma dose de $1 \mathrm{mg} / \mathrm{kg}$ de Dexametasona (grupo DEX $+\angle P S$ ) e o grupo controle negativo recebeu doses diárias de veículo mas sem LPS (grupo Controle Veículo). Vinte e quatro horas após a administração do LPS, os olhos foram enucleados, humor aquoso foi recolhido, e o número de células infiltrativas, a concentração de proteína, assim como os níveis de óxido nítrico (NO), fator de necrose tumoral a (TNF-a), interleucina- 6 e marcadores de estresse oxidativo foram determinados no humor aquoso. Além disso, a resposta inflamatória foi avaliada clinicamente e histologicamente.

Resultados: As células infiltrativas, concentração de proteína, o NO, TNF-a, interleucina-6 foram significativamente elevados no humor aquoso de ratos do grupo Grupo LPS + Veículo quando comparados ao Grupo Controle Veículo. O tratamento com licopeno diminuiu significativamente estes aumentos. Comparado ao Grupo LPS + Veículo, o licopeno reduziu significativamente as concentrações no humor aquoso dos marcadores de estresse oxidativo e NO (de 0,29 $\pm 0,1 \mu \mathrm{M}$ para 0,19 $\pm 0,1 \mu \mathrm{M}, p=0,003)$, o TNF- $a$ (de $71,0 \pm 22,3 \mathrm{ng} / \mathrm{m} /$ para 50,1 $\pm 2,1 \mathrm{ng} / \mathrm{ml}, p=0,043$ ), interleucina- 6 (de $121,6 \pm$ $3,0 \mathrm{pg} / \mathrm{m} /$ para $111,1 \pm 5,6 \mathrm{pg} / \mathrm{ml}, p=0,008)$. Do mesmo modo, o aumento do número de células infiltrativas no tecido uveal em seções histológicas foi significativamente inibido pelo licopeno, a pontuação inflamatória diminuiu de 2,0 $\pm 0,0$ para 0,4 \pm 0,5, $p=0,001$. Embora, não tenha sido estatisticamente significativo, o licopeno reduziu a contagem de células infiltrativas e a concentração de proteínas no humor aquoso.

Conclusões: Estes resultados sugerem que o licopeno pode ter efeitos benéficos no tratamento da inflamação ocular, através dos seus efeitos anti-inflamatórios e antioxidantes.

Descritores: Uveíte/induzido quimicamente; Endotoxinas; Estresse oxidativo; Antioxidantes; Inflamação; Citocinas; Animais; Modelos animais de doenças; Ratos

\section{INTRODUCTION}

Uveitis is an intraocular inflammatory disorder that accounts for up to $10 \%-25 \%$ of legal blindness worldwide ${ }^{(1,2)}$. It primarily affects the uvea, but may also involve adjacent structures such as the retina and vitreous. Although autoimmune diseases and infections are considered main causes, the exact mechanisms of pathogenesis remain unclear ${ }^{(2,3)}$. Endotoxin-induced uveitis (EIU) in rats, which mimics human idiopathic nonspecific acute uveitis, is an established model for evaluating the therapeutic efficacy of potential treatments, especially those that may prevent or stop ocular inflammation ${ }^{(4)}$. Lipopolysaccharide (LPS), the main component of the cell walls of gram-negative bacteria, generates an acute inflammatory response in EIU. LPS is recognized by membrane-bound receptors, principally on the surface of macrophages, and triggers the release of proinflammatory factors, such as tumor necrosis factor-a (TNF-a), interlukin-6 (IL-6), nitric oxide (NO), and monocyte chemoattractant protein- $1^{(5)}$. The inflammatory response to LPS also induces oxidative stress ${ }^{(6)}$. Eventually the initiated proinflammatory cascades results in the breakdown of the blood-
Submitted for publication: January 18, 2016

Accepted for publication: August 28, 2016

Department of Ophthalmology, Harran University, School of Medicine, Sanliurfa, Turkey.

2 Department of Medical Pharmacology, School of Medicine, Harran University, Sanliurfa, Turkey.

${ }^{3}$ Department of Medical Biochemistry, School of Medicine, Harran University, Sanliurfa, Turkey.

${ }^{4}$ Department of Medical Pathology, School of Medicine, Harran University, Sanliurfa, Turkey.
Funding: This study was supported by grants from the Harran University Scientific Research Council (HUBAK-14112).

Disclosure of potential conflicts of interest: None of the authors have any potential conflict of interest to disclose.

Corresponding author: Tuğba Göncü. Department of Ophthalmology, Faculty of Medicine, Harran University, Sanliurfa, 63300 - Turkey - E-mail: drtgoncu@hotmail.com

Approved by the following research ethics committee: Dollvet Animal Care and Use in Research Ethics Committee (Project number: 2014/51). 
ocular barrier and the infiltration of leukocytes into both anterior and posterior segments of the eye, which contributes to the further progression of EIU(4)

Lycopene is a dietary carotenoid present in tomatoes and other red fruits and vegetables such as watermelon and pink grapefruit ${ }^{(7)}$. It has been reported that dietary intake of tomato and tomato-derived products can reduce the risks of chronic diseases and various cancers, especially prostate cancer ${ }^{(8,9)}$. Lycopene is a potent antioxidant as well as an inhibitor of proinflammatory and prothrombotic factors ${ }^{(10)}$, although the mechanisms for these additional activities have not been clarified. Lycopene was shown to inhibit formation of proinflammatory cytokines and chemokines in macrophages ${ }^{(11,12)}$. The inherent antioxidant activity of lycopene may contribute to immune system modulation ${ }^{(13,14)}$.

In the present study, we evaluated the efficacy of lycopene against EIU-associated inflammation and oxidative stress in rats by histopathologic and biochemical analyses. Another aim was to compare the anti-inflammatory effects of lycopene to those of dexamethasone, which is currently the standard treatment for uveitis.

\section{METHODS}

\section{Chemicals}

Lycopene was supplied by DSM Nutritional Products (Istanbul, Turkey). Lipopolysaccharide from Salmonella typhimurium was obtained from Sigma-Aldrich (St. Louis, MO, US) and dexamethasone from Deva Pharmaceuticals (Tekirdag, Turkey). Rat TNF-a, IL-6, and NO enzyme-linked immunosorbent assay (ELISA) kits were obtained from Ray Biotech Inc. (Norcross, GA, US), Diaclone (Besançon cedex, France), and Cayman Chemical Inc. (Ann Arbor, MI, US), respectively.

\section{Animals and experimental protocol}

This study was conducted on 28 healthy, 6-8-week-old adult Sprague-Dawley rats weighing 240-275 g obtained from Dollvet Animal Laboratory (Sanliurfa, Turkey), where the experiments were also performed. The study was performed in accordance with National Institutes of Health guidelines for the Care and Use of Laboratory Animals and the Association for Research in Vision and Ophthalmology (ARVO) Statement for the Use of Animals in Ophthalmic and Vision Research. The study was also approved by the Dollvet Animal Care and Use Committee (Approval number: 2014/51). The animals were allowed to acclimate under standard laboratory conditions (12-h light; 12 -h dark) in a room with controlled temperature $\left(24 \pm 3^{\circ} \mathrm{C}\right)$ for one week prior to experiments. The animals had free access to water and were fed a standard commercial pellet diet ad libitum.

Endotoxin-induced uveitis (EIU) was induced by a single subcutaneous injection of LPS $(200 \mu \mathrm{g})$ dissolved in $0.1 \mathrm{ml}$ sterile saline as described previously ${ }^{(4)}$. The dosing protocols were based on previous studies ${ }^{(15-17)}$. After seven days of acclimatization, the animals were randomly divided into four groups: Vehicle Control (vehicle only, $n=6$ ), vehicle pretreatment then LPS (Vehicle + LPS, $n=6$ ), lycopene pretreatment then LPS (Lycopene + LPS, $\mathrm{n}=7$ ), and a positive control receiving dexamethasone pretreatment (DEX + LPS, $n=7$ ). In the Vehicle Control group, vehicle $(0.9 \% \mathrm{NaCl})$ was administered by intraperitoneal injection for three consecutive days at $1 \mathrm{ml} /$ injection, followed by $0.1 \mathrm{ml}$ vehicle instead of LPS. The Vehicle + LPS group received vehicle as pretreatment then subcutaneous LPS injection on day three at 200 mg/0.1 ml. The Lycopene + LPS group received daily intraperitoneal injection of $10 \mathrm{mg} / \mathrm{kg}$ lycopene for three consecutive days, then subcutaneous injection of LPS at $200 \mu \mathrm{g} / 0.1 \mathrm{ml}$. The positive control DEX + LPS group received LPS at $200 \mu \mathrm{g} / 0.1 \mathrm{ml}$ immediately after intraperitoneal injection of $1 \mathrm{mg} / \mathrm{kg}$ dexamethasone.

Twenty-four hours after LPS or final vehicle administration, eyes were examined under microscopy and enucleated. The aqueous humor was collected from both eyes (15-25 $\mu$ l) by anterior chamber puncture with a 30-gauge needle under a surgical microscope. One of the eyes was fixed with $10 \%$ buffered formalin solution at room tempe- rature for histopathological evaluation, and the other was stored at $-80^{\circ} \mathrm{C}$ for biochemical analyses.

\section{BIOCHEMICAL MEASUREMENTS}

To count infiltrating cells, the aqueous humor samples were suspended in an equal volume of Turk stain solution (Merck, Darmstadt, Germany) and examined by a hemocytometer under light microscopy. The number of cells was obtained by averaging the results of four randomly chosen fields from each sample. The aqueous humor samples were stored in ice water until testing, and cell counts were measured on the day of sample collection. The microprotein level was measured by the Lowry method ${ }^{(18)}$. The concentrations of TNF-a, NO, and IL-6 were measured using commercially available rat ELISA kits.

\section{ANALYsis OF OXIDATIVE STRESS MARKERS IN THE AQUEOUS HUMOR AND OCULAR TISSUE}

The crystalline lens was removed from enucleated eyes due to the high glutathione concentration ${ }^{(19)}$. Ocular tissues were weighed, broken down into very small pieces and placed in empty glass tubes. Then, $1 \mathrm{ml}$ of $140 \mathrm{mM} \mathrm{KCl}$ solution per gram of tissue was added to each tube, and all tissues were homogenized in a motor-driven homogenizer. The homogenate was centrifuged at 2,800 $\times \mathrm{g}$ for 10 min at $4^{\circ} \mathrm{C}^{(20)}$. Total oxidant status (TOS), total antioxidant status (TAS), and oxidative stress index (OSI) were measured in supernatant and ocular tissue samples as described previously ${ }^{(21)}$. Briefly, TAS was measured spectrophotometrically using a commercial kit (Rel ${ }^{\circledR}$ Assay Diagnostics Mega Tip San. ve Tic. Ltd. Sti., Gaziantep, Turkey). TAS measurements of aqueous humor are expressed as mmol Trolox equivalent/L and TAS measurements of ocular tissue as mmol Trolox equivalent/gram protein. TOS was also measured in samples spectrophotometrically using commercial kits (Re ${ }^{\circledR}$ Assay Diagnostics, Mega Tip San. ve Tic. Ltd. Sti., Gaziantep, Turkey) and expressed as micromolar hydrogen peroxide per liter ( $\mu \mathrm{mol} \mathrm{H}_{2} \mathrm{O}_{2}$ equivalent/L) or $\mu \mathrm{mol}$ $\mathrm{H}_{2} \mathrm{O}_{2}$ equivalent/gram protein as appropriate. OSI was defined as the percentage ratio of TOS to TAS.

\section{Clinical manifestations scoring}

Clinical features of ocular inflammation were evaluated in both eyes $24 \mathrm{~h}$ after LPS or final vehicle injection using a slit lamp. Severity was graded from 0 to 4 by an observer blind to treatment history as described previously ${ }^{(22)}$. The clinical grading was defined as follows: Grade 0 was defined as no obvious inflammatory response, Grade 1 as discrete dilation of the iris and conjunctival vessels, Grade 2 as moderate dilation of the iris and conjunctival vessels with moderate flare in the anterior chamber, Grade 3 as intense iridal hyperemia with intense flare in the anterior chamber, and Grade 4 as the clinical signs of Grade 3 plus fibrinous exudation and miosis.

\section{Histopathological examination}

For histopathologic analysis, enucleated eye specimens were dissected from anterior to posterior and fixed in 10\% neutral formalin for $48 \mathrm{~h}$. Routine tissue processing protocols were performed and tissues were embedded in paraffin. Three or five sections of 4- to 5- $\mu$ m thickness were cut from each specimen and stained with hematoxylin and eosin. Histopathologic findings in the uveal structures and cornea were scored as described previously ${ }^{(23)}$. Grade 0 was defined as normal tissue. Grade 1 was defined as dilated iris vessels and thickened iris stroma with exudate, protein, and/or a few scattered inflammatory cells in the anterior chamber. Grade 2 was defined as infiltration of inflammatory cells into the stroma of the iris and/or ciliary body with a moderate number of inflammatory cells within the anterior chamber. Grade 3 was defined as heavy infiltration of inflammatory cells within the iris stroma, ciliary body, and the anterior chamber. Grade 4 indicated heavy exudation of cells, dense protein aggregation in the anterior chamber, and inflammatory cell deposits on the corneal endothelium. Histopathologic analyses were performed by a single pathologist blinded to treatment history. 


\section{Statistical analyses}

Biochemical and histopathological measurements are reported as mean \pm standard deviation. All group data were compared by non-parametric Kruskal-Wallis tests. The Mann-Whitney $U$ test was used to compare paired groups. A p-value less than 0.05 was regarded as statistically significant. Data analyses were performed using the statistical software SPSS for Windows (version 18.0).

\section{RESULTS}

\section{Cellular infiltration in the aqueous humor}

The number of infiltrating cells in the aqueous humor $24 \mathrm{~h}$ after LPS injection was significantly elevated compared to the Vehicle Control group $(946 \pm 1125$ cells/ $\mu \mathrm{l}$ vs. $6 \pm 16$ cells $/ \mu \mathrm{l})$. Pretreatment with lycopene before LPS resulted in a substantial reduction of cell number to $342 \pm 221$ cells/ $\mu$ l, although the difference was not statistically significant (Vehicle + LPS vs. Lycopene + LPS, $p=0.472$ ). Pretreatment with dexamethasone (DEX + LPS Group) also reduced cell number, which was statistically significant $(120 \pm 71$ cells $/ \mu$ l, $p=0.004)$. The magnitude of the mean lycopene effect was comparable to that of dexamethasone $(p=0.111)$ (Figure $1 \mathrm{~A})$.

\section{Protein concentration in the aqueous humor}

The protein concentration in the aqueous humor of the Vehicle + LPS group was significantly elevated compared to Vehicle Control
$(11.0 \pm 3.1 \mathrm{mg} / \mathrm{dl}$ vs. $1.5 \pm 1.5 \mathrm{mg} / \mathrm{dl})$ and was not significantly reduced by lycopene pretreatment (Lycopene + LPS: $8.4 \pm 6.0 \mathrm{mg} / \mathrm{dl}$, $p=0.534$ ), while dexamethasone pretreatment (DEX + LPS) did significantly reduce protein concentration in the aqueous humor compared to the Vehicle + LPS group $(1.9 \pm 0.1 \mathrm{mg} / \mathrm{dl}, \mathrm{p}=0.002)$. Thus, the efficacy of lycopene was less than that of dexamethasone $(p=0.022)$ (Figure 1 B)

\section{TNF- $\alpha$ CONCENTRATION IN THE AQUEOUS HUMOR}

The aqueous humor TNF-a concentration was significantly higher in the Vehicle + LPS group than the Vehicle Control group (71.0 \pm $22.3 \mathrm{ng} / \mathrm{ml}$ vs. $48.4 \pm 0.8 \mathrm{ng} / \mathrm{ml}$ ) and was significantly reduced by both lycopene pretreatment (Lycopene + LPS, $50.1 \pm 2.1 \mathrm{ng} / \mathrm{ml}, \mathrm{p}=0.043$ ) and dexamethasone pretreatment (DEX + LPS: $50.0 \pm 1.2 \mathrm{ng} / \mathrm{ml}$, $p=0.035$ ). Moreover, the suppressive effect of lycopene was comparable to that of dexamethasone $(p=0.662)$ (Figure $2 \mathrm{~A})$.

\section{NO CONCENTRATION IN THE AQUEOUS HUMOR}

In the Vehicle + LPS control, NO concentration in the aqueous humor was also higher than in the Vehicle control group $(0.29 \pm 0.1 \mu \mathrm{M}$ vs. $0.14 \pm 0.0 \mu \mathrm{M})$ and again was significantly reduced by lycopene pretreatment $(0.19 \pm 0.1 \mu \mathrm{M}, \mathrm{p}=0.003)$ and dexamethasone pretreatment $(0.21 \pm 0.06 \mu \mathrm{M}, \mathrm{p}=0.043)$. The inhibitory effect of lycopene on $\mathrm{NO}$ accumulation was comparable to that of dexamethasone $(p=0.352)$ (Figure 2 B)
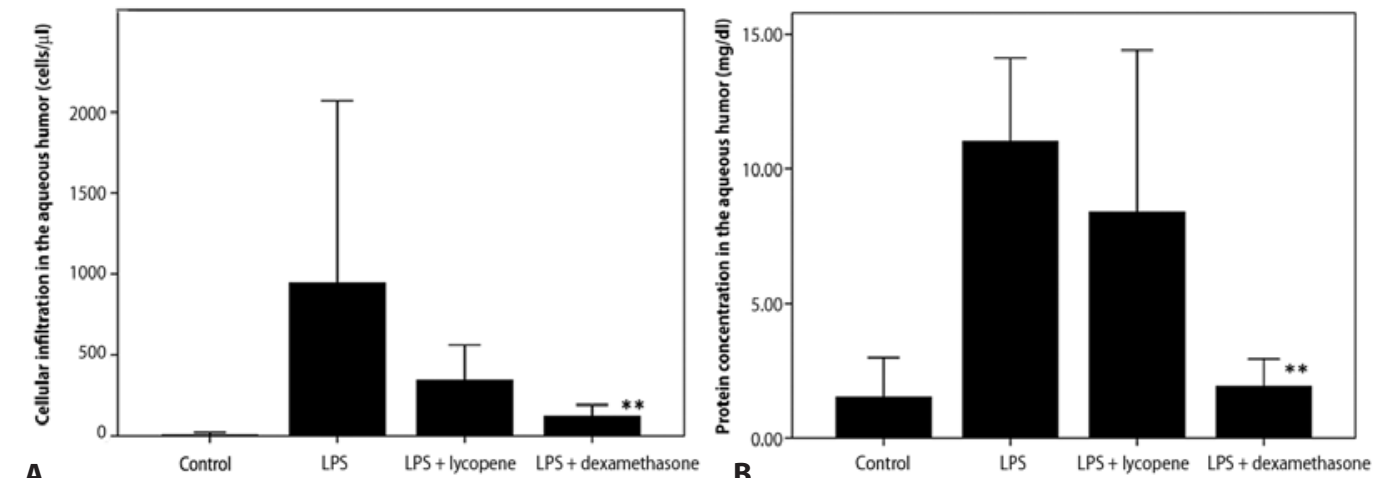

*** $p<0.01$ significantly different from the Vehicle + LPS group.

Figure 1. Effects of lycopene on cell infiltration and protein accumulation in the aqueous humor following lipopolysaccharide (LPS)-induced uveitis. Lycopene pretreatment (Lycopene + LPS group) reduced cell infiltration A) and mildly suppressed protein exudation B) in aqueous humor compared to vehicle (Vehicle + LPS group). Dexamethasone pretreatment was used as a positive control (DEX + LPS). All data are shown as mean \pm standard deviation.
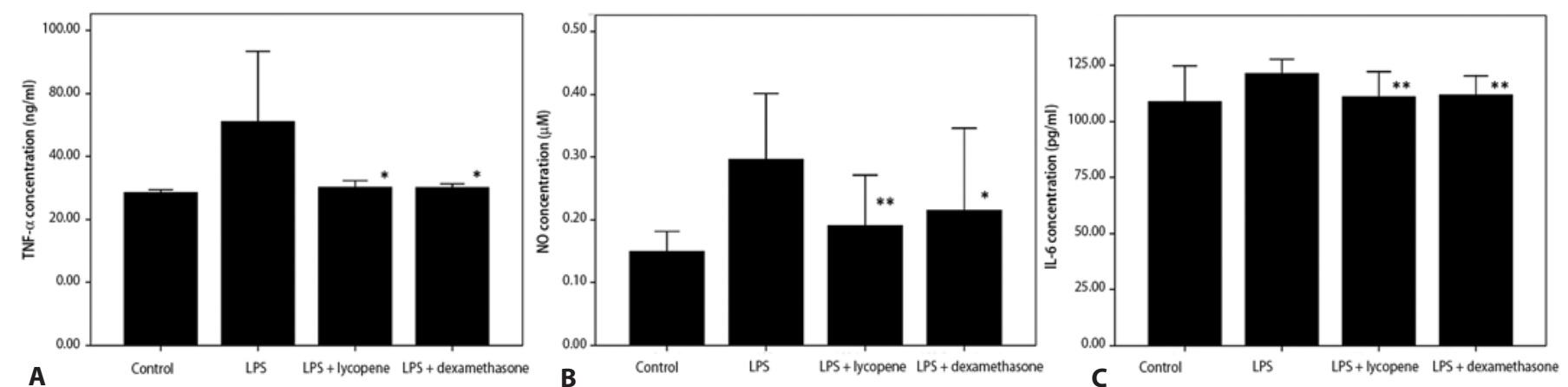

${ }^{*} p<0.05$ and ${ }^{*} p<0.01$ significantly different from the Vehicle + LPS group.

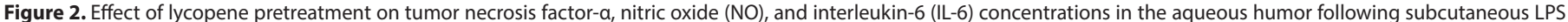

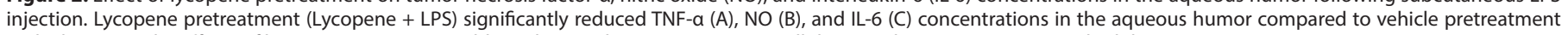
(Vehicle + LPS). The effects of lycopene were comparable to dexamethasone (DEX + LPS). All data are shown as mean \pm standard deviation. 


\section{IL-6 CONCENTRATION IN THE AQUEOUS HUMOR}

The IL-6 concentration in the aqueous humor was higher in the Vehicle + LPS group than in the Vehicle Control group (121.6 \pm $3.0 \mathrm{pg} / \mathrm{ml}$ vs. $108.9 \pm 7.9 \mathrm{pg} / \mathrm{ml}$ ) and, consistent with effects on NO and TNF-a, was significantly reduced by lycopene $(111.1 \pm 5.6 \mathrm{pg} / \mathrm{ml}$, $p=0.008)$ and by dexamethasone pretreatment $(111.9 \pm 4.3 \mathrm{pg} / \mathrm{ml}$, $p=0.004)$. The effect of lycopene was comparable to that of dexamethasone $(p=0.666)$ (Figure 2C).

\section{Oxidative Stress markers in the aQueOus HUMOR}

The mean OSI in the aqueous humor was higher in the Vehicle + LPS group than in the Vehicle Control group (14.5 $\pm 0.3 \mathrm{AU}$ vs. $8.9 \pm 2.2 \mathrm{AU})$ and was reduced by both lycopene $(12.2 \pm 3.6 \mathrm{AU}, \mathrm{p}=0.025)$ and dexamethasone pretreatment (11.9 $\pm 1.2 \mathrm{AU}, \mathrm{p}=0.008)$. The effect of lycopene was comparable to dexamethasone $(p=0.657)$ (Figure $3 \mathrm{~A}$ ).

\section{Oxidative STRESS INDICATORS IN OCULAR TISSUE}

Mean OSI in the ocular tissue was higher in the LPS-treated group than the Vehicle Control group ( $1.5 \pm 0.1 \mathrm{AU}$ vs. $0.9 \pm 0.2 \mathrm{AU}$ ) and was reduced moderately but not significantly by lycopene pretreatment
(1.2 $\pm 3.6 \mathrm{AU}, \mathrm{p}=0.775)$. In contrast, dexamethasone pretreatment significantly reduced OSI compared to the Vehicle + LPS group (1.0 \pm $0.2 \mathrm{AU}, \mathrm{p}=0.004)$. The magnitude of the average lycopene effect was comparable with that of dexamethasone $(p=0.101)$ (Figure 3 B).

\section{Clinical scores of intraocular inflammation}

The clinical score $24 \mathrm{~h}$ after LPS injection was $3.5 \pm 0.7$, significantly higher than in rats pretreated with lycopene $(2.3 \pm 0.4, p=0.014)$. Dexamethasone pretreatment also reduced the clinical score (1.2 \pm 0.8 , $p=0.002)$ with a larger effect than lycopene (Lycopene + LPS vs. DEX + LPS, $p=0.014$ ) (Figure 4).

\section{Histopathology SCORES}

No infiltrating cells were detected in the ocular sections of the Vehicle Control group. The histopathologic score $24 \mathrm{~h}$ after LPS injection (Vehicle + LPS group) was reduced significantly by lycopene pretreatment $(2.0 \pm 0.0$ vs. $0.4 \pm 0.5, p=0.001)$. Similarly, dexamethasone pretreatment significantly reduced histopathologic grade $(0.7 \pm 0.5, p=0.002)$. The efficacies of lycopene and dexamethasone were comparable $(p=0.409)$ (Figure 5).
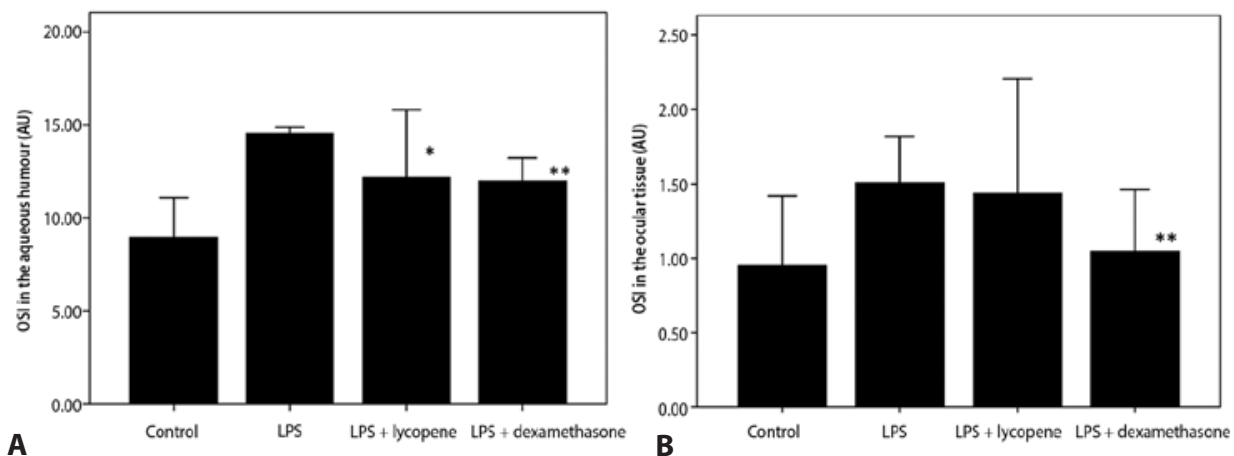

${ }^{*} p<0.05$ and ${ }^{* *} p<0.01$ significantly different from the Vehicle + LPS group.

Figure 3. Effect of lycopene pretreatment on oxidative stress index (OSI) in the aqueous humor following LPS injection. Lycopene pretreatment caused a significant reduction in OSI in the aqueous humor (A) compared to vehicle (Vehicle + LPS). Lycopene also reduced OSI in ocular tissue (B) compared to vehicle but the effect did not reach significance $(p>0.05)$. All data are shown as mean \pm standard deviation.

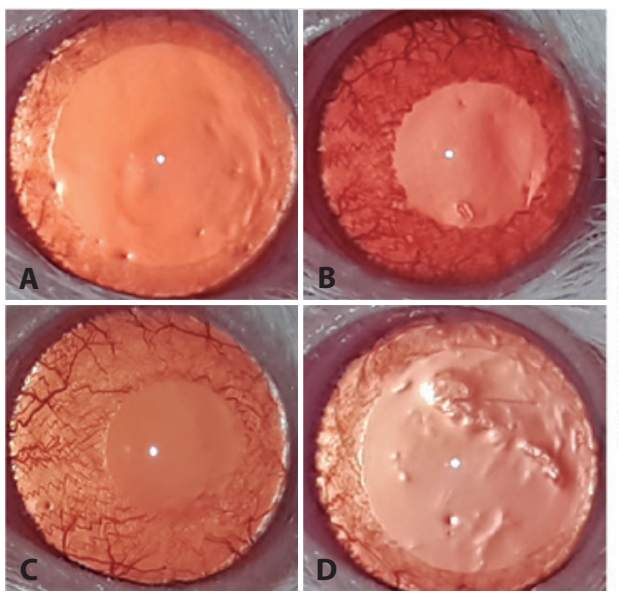

$\mathbf{E}$

$\mathrm{p}<0.05$ significantly different from Vehicle + LPS.

Figure 4. Effect of lycopene on clinical manifestations of intraocular inflammation. Ocular inflammation was evaluated by microscopic examination $24 \mathrm{~h}$ after lipopolysaccharide (LPS) injection. No inflammatory reaction was observed in vehicle-treated controls (A). Anterior segment examination revealed an inflammatory reaction consisting of hyperemia and edema associated with miosis and fibril formation in the anterior chamber following LPS (B). The inflammatory reaction was suppressed by pretreatment with lycopene $(C)$ and by pretreatment with dexamethasone (D). Lycopene pretreatment caused a significant improvement in clinical score compared to vehicle following LPS (E). All data shown as mean \pm standard deviation. 

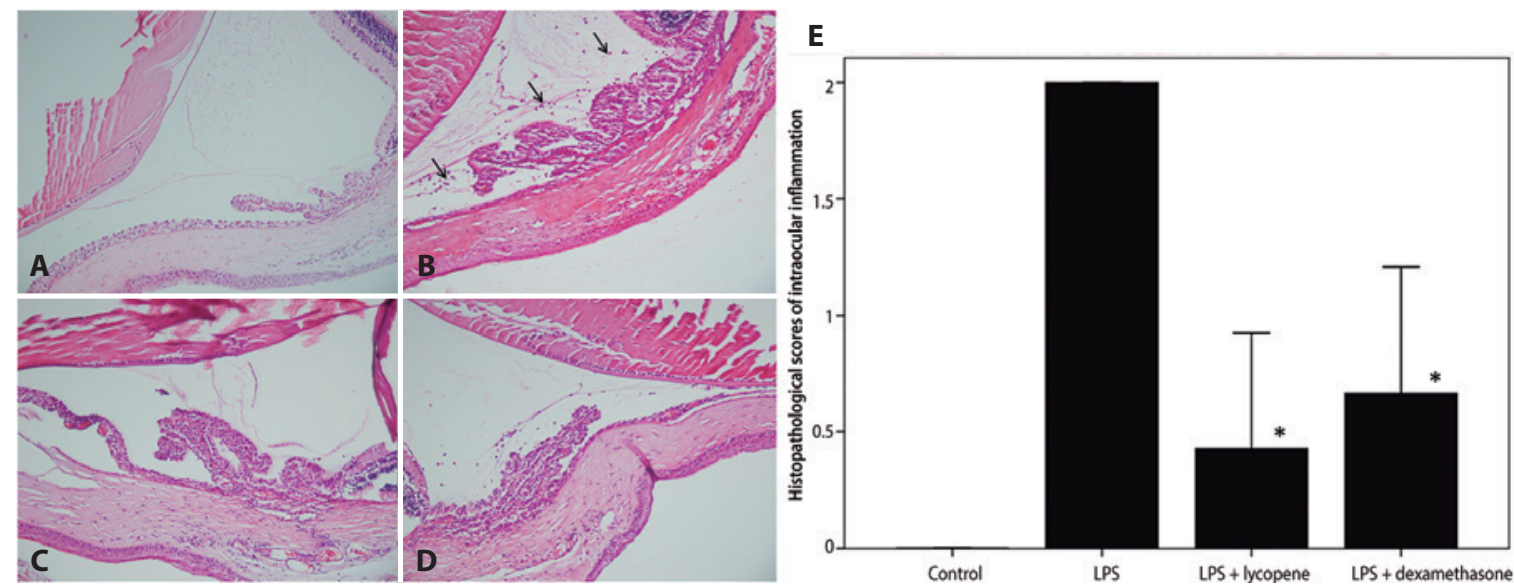

*p $<0.05$ significantly different from the Vehicle + LPS group.

Figure 5. The effect of lycopene pretreatment on histopathological signs of intraocular inflammation following LPS. No inflammatory cells were observed in the Vehicle Control group (A). Numerous inflammatory cells (black arrows) infiltrated the extravascular uveal tissue in the Vehicle + LPS group (B). Inflammatory cellular infiltration was reduced by pretreatment with lycopene (Lycopene + LPS) (C) or dexamethasone (DEX + LPS) (D). Hematoxylin and eosin staining, magnification $\times 200$. Lycopene pretreatment significantly improved clinical scores compared to vehicle pretreatment $(E)$. All data shown as mean \pm standard deviation.

\section{DISCUSSION}

Lycopene, a natural dietary carotenoid, may reduce the risks of chronic diseases and various cancers ${ }^{(8,9)}$. It has been reported that lycopene reduces proinflammatory cytokine and chemokine expression in macrophages ${ }^{(11,12)}$, which may account, at least in part, for these health benefits. Accumulating evidence also suggests that modulation of intracellular gap junction communication, metabolic pathways, and other immune system functions contribute to lycopene effica$c y^{(13,14)}$. Furthermore, lycopene suppresses inflammation in several tissues by inhibiting the formation of proinflammatory molecules such as $\mathrm{NO}$, interleukins, and cyclooxygenase $\mathrm{e}^{(9,11,12)}$.

Uveitis is an inflammatory intraocular disorder afflicting the uvea, a highly vascular tissue. Due to as yet unclear etiopathological factors for formation and progression, there is no definitive treatment for autoimmune uveitis. Corticosteroids are currently the primary treatment choice, but steroid use is associated with serious complications, including glaucoma and cataract ${ }^{(24,25)}$. The identification of new anti-inflammatory compounds is thus required to reduce the complications induced by corticosteroids. Accordingly, numerous clinical and experimental studies have been conducted evaluating nonsteroidal treatment strategies for uveitis ${ }^{(15,26-28)}$. Endotoxin-induced uveitis is a useful model for this purpose. LPS stimulates the inflammatory response by activating expression and release of inflammatory cytokines such as TNF-a, IL-6, and monocyte chemoattractant protein-1, as well as $\mathrm{NO}^{(5)}$. In addition to direct activation of inflammatory cytokines by LPS, the resulting oxidative stress is known to modulate inflammatory signaling ${ }^{(6)}$. Furthermore, oxidative damage is exacerbated by NO generation. Thus, we speculated that lycopene, a known immunosuppressant and antioxidant, would suppress uveitis.

In the present study, we demonstrate for the first time that lycopene has significant anti-inflammatory efficacy in the rat EIU model. Cell count and protein concentration in the aqueous humor are useful indicators of blood-aqueous barrier integrity in EIU, and both were elevated by LPS. Also consistent with previous uveitis studies(5), TNF-a, NO, and IL-6 concentrations were elevated in the aqueous humor of LPS-induced EIU rats, and the levels of all three factors were reduced by lycopene pretreatment. In fact, the magnitudes of these reductions were comparable to dexamethasone, the primary clinical treatment against uveitis. Consistent with suppression of inflammatory factors, the clinical severity and histological signs of inflammation were improved substantially by lycopene. While lycopene was not as effective as dexamethasone in reducing cell count and protein concentration in the aqueous humor, $10 \mathrm{mg} / \mathrm{kg}$ lycopene was as effective or better than $1 \mathrm{mg} / \mathrm{kg}$ dexamethasone for reducing histopathological signs (as evidenced by the slightly greater reduction in histopathological grade). Lycopene pretreatment lowered OSI in both the aqueous humor and ocular tissue, although the effect was significant only in the aqueous humor, possibly due to limited tissue access. Given that oxidative stress contributes to the pathogenesis of LPS-induced inflammation, these reductions may explain the improved clinical and histopathological signs of inflammation.

Other carotenoids, such as lutein, fucoxanthin, and astaxanthin, also reduce inflammation in EIU ${ }^{(15,26-28)}$. The anti-inflammatory effects of lutein on EIU were attributed to inhibition of NF-אB-dependent signaling ${ }^{(15)}$, while astaxanthin was suggested to inhibit inflammation via suppression of NO, PGE2, and TNF-a by directly blocking nitric oxide synthase (NOS) activity ${ }^{(26,28)}$. Similarly, fucoxanthin was reported to act by suppressing PGE-2 and NO production ${ }^{(27)}$. Thus, all these carotenoids appear to share at least some anti-inflammatory mechanisms.

In mice, the anti-inflammatory effects of lycopene against LPS stimulation depend on inhibition of $\mathrm{NO}$ and IL-6 production as well as suppression of NF- $\mathrm{BB}$ transcriptional activity and associated downstream pathways ${ }^{(29,30)}$. Our findings are consistent with these results, confirming that the anti-inflammatory activities of lycopene are mediated by inhibition of TNF-a, NO, and IL-6 production, resulting in reduced uveal inflammation.

Limitations of this study include the lack of pharmacokinetic, mechanistic, and functional analyses. We only assessed a brief three-day pretreatment protocol and did not measure intraocular lycopene levels. Such measurements could explain the differences in antioxidant efficacy between vitreous humor and tissue. We also did not evaluate the dose-response relationship, studies needed to define the optimal dosing protocol. While relief of oxidative stress is expected as carotenoids are free-radical scavengers, we did not assess specific mechanisms underlying the anti-inflammatory effects. In addition, we did not examine the reasons for greater dexamethasone efficacy against specific pathological indices, particularly blood-ocular barrier breach. Finally, functional recovery of vision was not assessed.

In conclusion, our study demonstrates for the first time that systemic administration of lycopene can attenuate inflammation and oxidative stress induced by LPS in a rat model of EIU. In addition, we show that most benefits of lycopene treatment are comparable to those of 
dexamethasone, which has well-known clinical efficacy against uveitis. Therefore, lycopene may prove beneficial for the management of uveitis, a major cause of blindness, while obviating the deleterious effects of steroid treatment.

\section{REFERENCES}

. Dandona L, Dandona R, John RK, McCarty CA, Rao GN. Population based assessment of uveitis in an urban population in southern India. Br J Ophthalmol. 2000;84(7):706-9.

2. Nussenblatt RB. The natural history of uveitis. Int Ophthalmol. 1990;14(5-6):303-8.

3. Gupta R, Murray PI. Chronic non-infectious uveitis in the elderly: epidemiology, pathophysiology and management. Drugs Aging 2006;23(7):535-58.

4. Rosenbaum JT, McDevitt HO, Guss RB, Egbert PR. Endotoxin-induced uveitis in rats as a model for human disease. Nature. 1980;286(5773):611-3.

5. De Vos AF, Hoekzema R, Kijlstra A. Cytokines and uveitis, a review. Curr Eye Res. 1992; 11(6):581-97.

6. Satici A, Guzey M, Gurler B, Vural H, Gurkan T. Malondialdehyde and antioxidant enzyme levels in the aqueous humor of rabbits in endotoxin-induced uveitis. Eur J Ophthalmol. 2003:13(9-10):779-83.

7. Clinton SK. Lycopene: chemistry, biology, and implications for human health and disease. Nutr Rev. 1998:56(2 Pt 1):35-51.

8. Giovannucci E. Tomatoes, tomato-based products, lycopene, and cancer: review of the epidemiologic literature. J Natl Cancer Inst. 1999;91(4):317-31.

9. Agarwal S, Rao AV. Tomato lycopene and its role in human health and chronic diseases. CMAJ. 2000;163(6):739-44

10. Türk G, Ceribaşi AO, Sakin F, Sönmez M, Ateșşahin A. Antiperoxidative and anti-apoptotic effects of lycopene and ellagic acid on cyclophosphamide-induced testicular lipid peroxidation and apoptosis. Reprod Fertil Dev. 2010;22(4):587-96.

11. Lee W, Ku SK, Bae JW, Bae JS. Inhibitory effects of lycopene on HMGB1-mediated pro-inflammatory responses in both cellular and animal models. Food Chem Toxicol. 2012; 50(6):1826-33.

12. Marcotorchino J, Romier B, Gouranton E, Riollet C, Gleize B, Malezet-Desmoulins C, et al. Lycopene attenuates LPS-induced TNF-a secretion in macrophages and inflammatory markers in adipocytes exposed to macrophage-conditioned media. Mol Nutr Food Res. 2012;56(5):725-32.

13. Zhang LX, Cooney RV, Bertram JS. Carotenoids up-regulate connexin43 gene expression independent of their provitamin A or antioxidant properties. Cancer Res. 1992;52(20): 5707-12.

14. Fuhrman B, Elis A, Aviram M. Hypocholesterolemic effect of lycopene and beta-carotene is related to suppression of cholesterol synthesis and augmentation of LDL receptor activity in macrophages. Biochem Biophys Res Commun. 1997;233(3):658-62.
15. Jin $X H$, Ohgami K, Shiratori K, Suzuki $Y$, Hirano T, Koyama $Y$, et al. Inhibitory effects of lutein on endotoxin-induced uveitis in Lewis rats. Invest Ophthalmol Vis Sci. 2006:47(6): 2562-8

16. Lin $\mathrm{HY}$, Huang BR, Yeh $\mathrm{WL}$, Lee $\mathrm{CH}$, Huang $\mathrm{SS}$, Lai $\mathrm{CH}$, et al. Antineuroinflammatory effects of lycopene via activation of adenosine monophosphate-activated protein kinase-a1/heme oxygenase-1 pathways. Neurobiol Aging. 2014;35(1):191-202.

17. Lee CM, Chang JH, Moon DO, Choi YH, Choi IW, Park YM, et al. Lycopene suppresses ovalbumin-induced airway inflammation in a murine model of asthma. Biochem Biophys Res Commun. 2008;374(2):248-52

18. Lowry OH, Rosebrough NJ, Farr AL, Randall RJ. Protein measurement with the Folin phenol reagent. J Biol Chem. 1951;193(1):265-75

19. Mérida S, Sancho-Tello M, Navea A, Almansa I, Muriach M, Bosch-Morell F. An anti-interleukin-2 receptor drug attenuates T-helper 1 lymphocytes-mediated inflammation in an acute model of endotoxin-induced uveitis. PLoS One 2014;9(3):e90216.

20. Rabus M, Demirbağ R, Sezen Y, Konukoğlu O, Yildiz A, Erel O, et al. Plasma and tissue oxidative stress index in patients with rheumatic and degenerative heart valve disease. Turk Kardiyol Dern Ars. 2008;36(8):536-40.

21. Cakmak A, Soker M, Koc A, Aksoy N. Prolidase activity and oxidative status in patients with thalassemia major. J Clin Lab Anal. 2010;24(1):6-11.

22. Pouvreau I, Zech JC, Thillaye-Goldenberg B, Naud MC, Van Rooijen N, de Kozak Y. Effect of macrophage depletion by liposomes containing dichloromethylene-diphosphonate on endotoxin-induced uveitis. J Neuroimmunol. 1998;86(2):171-81.

23. Tilton RG, Chang K, Corbett JA, Misko TP, Currie MG, Bora NS, et al. Endotoxin-induced uveitis in the rat is attenuated by inhibition of nitric oxide production. Invest Ophthalmol Vis Sci. 1994;35(8):3278-88

24. Bierly JR, Nozik RA. Management of uveitis. Curr Opin Ophthalmol. 1992;3(4):527-33.

25. Barry RJ, Nguyen QD, Lee RW, Murray PI, Denniston AK. Pharmacotherapy for uveitis: current management and emerging therapy. Clin Ophthalmol. 2014;8:1891-911.

26. Suzuki Y, Ohgami K, Shiratori K, Jin XH, llieva I, Koyama Y, et al. Suppressive effects of astaxanthin against rat endotoxin-induced uveitis by inhibiting the NF-kappaB signaling pathway. Exp Eye Res. 2006;82(2):275-81

27. Shiratori K, Ohgami K, Ilieva I, Jin XH, Koyama Y, Miyashita K et al. Effects of fucoxanthin on lipopolysaccharide-induced inflammation in vitro and in vivo. Exp Eye Res. 2005; 81(4):422-8

28. Ohgami K, Shiratori K, Kotake S, Nishida T, Mizuki N, Yazawa K, et al. Effects of astaxanthin on lipopolysaccharide-induced inflammation in vitro and in vivo. Invest Ophthalmo Vis Sci. 2003;44(6):2694-701.

29. Feng D, Ling WH, Duan RD Lycopene suppresses LPS-induced NO and IL-6 production by inhibiting the activation of ERK, p38MAPK, and NF-kappaB in macrophages. Inflamm Res. 2010;59(2):115-21.

30. Joo Y-E, Karrasch T, Mühlbauer M, Allard B, Narula A, Herfarth HH, et al. Tomato lycopene extract prevents lipopolysaccharide-induced $\mathrm{nf}-\mathrm{kb}$ signaling but worsens dextran sulfate sodium-induced colitis in NF-KBEGFP mice. PLoS One 2009;4(2):e4562.

\title{
3 을 Congresso de Oftalmologia da Universidade Federal de Goiás
}

\section{6 e 17 de junho de 2017}

\author{
Sede do Conselho Regional de Medicina do Estado de Goiás
}

Goiânia - GO

\section{Informações:}

Tel.: (62) 3928-1416

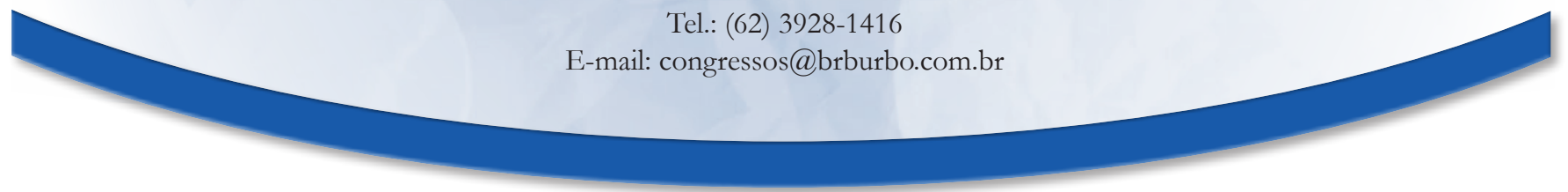

